\title{
The difficulties facing West German science
}

What is the current state of science in West Germany?

Rainer Flohl reports on a situation which scientists in other developed countries may find familiar

SCIENTIFIC research in West Germany is going through a difficult period. It is suffering from financial restrictions similar to those in many other countries. More importantly, it has been affected by the structural changes in West German universities over the past few years. Indeed, after a belated advance in the mid-1960s, when it received increased government support, West German science again stands on the brink of disaster. The winner of the Nobel Prize for Chemistry, O. E. Fischer of the Munich Technical University, has asserted that West German universities are losing ground in international terms. He compares research units in West German institutions of higher learning to empty shells, and the strong teams in AngloSaxon countries to battleships. German scientists cannot hold their own against this kind of opposition: the once-successful Geheimratsystem has disappeared, and with it has gone the glamour which had attracted scientists to West Germany from all over the world.

The overthrow of that system was in fact a reaction to the growing demands of an ever more complex science. The anticipated consequences -intensified cooperation among scientists, greater "teamwork", more criticism and self-criticism-have failed to materialise. But this failure was disguised in the early 1960s when increased financial support for science led to a certain amount of progress. Now the deterioration is apparent, though the true situation is not generally understood. There are three reasons for the deterioration: the aforesaid structural change; the overburdening of universities with teaching; and the financial crisis, which has drastically exposed the weak position of science.

The overburdening with work of teachers in higher institutions is the result of the explosion of further education, which even now continues to attract more and more students to universities. Growing numbers of university teachers were needed to instruct the students. These teachers wished not only to teach, but also-in the German tradition of "unity of research and teaching"- to carry out research for themselves. This has led to a doubling of the number of scientists in the Federal Republic over the past few years. The means for research work have not risen proportionately, so the average research worker has less money than at any previous time. Besides this, the lecturers have had to spend more time on their teaching. Only in this way could they keep up with the rising number of students, whose education-for political reasons --appears to be more important than research work. The time available for research has been reduced because the democratisation of higher education demands too many meetings and additional administrative expenses.

The financial crisis has led to a drastic reduction in the funds available for research. Many programmes have had to be arbitrarily curtailed. In 1975 approximately 30 to $40 \%$ of allocated funds were withdrawn; there will be no change in the situation in 1976. People have accepted the change without complaining. Unrest at the universities has subsided. The only remaining tensions are in the departments responsible for teacher training; but fully qualified students have increasing difficulty in finding work, which makes them insecure. Many of them blame the socalled Radikalenerlass rather than their own poor marks for their failure. The Radikalenerlass was an administrative regulation designed to prevent professed enemies of the constitution-in particular members of the Communist Party-from getting jobs in the public service. Many rumours arose because of the generally clumsy and bureaucratic methods used to check public service applicants. It was said, among other things, that a signature on a pamphlet was sufficient to get an applicant rejected. The regulation has recently been abolished, or rather administered in a different manner.

The Federal Republic has encountered these problems at a time when there were justifiable hopes of improving the effectiveness of scientific research. The two most important organisations conducting pure research in the Federal Republic-the German Research Organisation (DFG) and the Max-Planck Institutes (MPG) - had elected new Presidents who were wellqualified and open to new ideas for reform. Professor H. Maier-Leibnitz, President of the DFG, which receives about DM600 million a year from the Federal and State governments for the furthering of basic research, has a wealth of experience and success as a practical scientist: he built the Federal Republic's first experimental reactor in Garching near Munich, and it was due to his initiative that the FrancoGerman high flux neutron reactor was later erected in Grenoble. Not least because of suggestions from Professor Maier-Leibnitz, both instruments became focal points of research, and he became an international figure through his contribution to neutron optics. The President of the Max-Planck Institute, Professor Reimar Lüst, is also a physicist. Formerly President of the European Space Research Organisation (ESRO) and Chairman of the German Science Council, Lüst was the first man to use barium clouds for the discovery of astrophysical phenomena. The MaxPlanck Institute also receives DM600 million from the Federal and State governments from funds set up to finance independent institutions.

Only time will tell whether Professor Maier-Leibnitz and the German Research Council will manage to restore science to its former position and thus unlock the creativity which is essential for successful research. The MaxPlanck Institutes' first priority is to protect scientists from the dead hand of the bureaucracy. But both institutions face exceptional problems,

\section{Sorry, for copyright \\ reasons some images on this page may not be available online}


especially as the "reform" of the universities has blocked posts for the new generation of scientists, however wellqualified, since large numbers of mediocre young scientists secured lifelong tenure in earlier years.

At the beginning of April the German Research Council published its Grauen Plan ("Gray Paper") analysing the present state of research in the Federal Republic. From its assessment of the present situation, and the many obvious deficiencies thus revealed, it derives suggestions for improving research, though it accepts that not all the ideas it puts forward can be carried out. The Paper covers the years 1976 to 1978 , and is the most detailed and honest document yet compiled about German research. The main section deals with the structure of the universities and the financing of research. For the first time, moreover, scientists from universities were consulted in the drawing up of the document: out of 1,300 scientists approached for their views on the state of research in universities and the condition of their own field of work, 1,000 responded. The results of this inquiry are also included in the Paper, which in parts is more a catalogue of inadequacies than the report of an enquiry, though it should not be overlooked that particular institutes are in fact in the lead internationally.

To overcome at least the financial stagnation of research, Professor Maier-Leibnitz called upon the Ministers of Culture and Science in the Federal Republic and its component States to increase the capacity for work in the country's universities, by promoting and supporting important research and at the same time making use of existing but insufficiently used research facilities. In this way, with less resources, a considerable improvement in quality could be achievedsomething which had been greatly neglected during the continuous expansion of higher education. An increase

\section{Sorry, for copyright \\ reasons some images \\ on this page may not \\ be available online}

\section{Students at Saarland University: for them, what sort of future?}

in the budget of $10 \%$ (DM60 million) would be sufficient to begin with, which amounts to only $\frac{1}{2} \%$ of the DM 13,000 million which is spent annually on higher education in the Federal Republic.

In this connection it must soon be clarified whether the balance between applied research and pure research is to be maintained in Germany. The former has expanded rapidly over the past few years through government grants. Those private institutions entrusted with the furtherance of science have so far refrained from open criticism of this development. To understand the problem it is only necessary to consider the vast sums which have been spent on applied research. Whereas the state granted DM850 million in 1974 to further general research in universities and private institutions, it allocated DM3,200 million for advanced programmes of applied technology (nuclear research and technology, space research and technology, data processing, marine research and other technology).

Criticism of the disproportion between applied research and pure research may be justified when it is considered that Germany is living on the results of past research, without worrying about the future. No politician seems to give serious consideration to the scientific source for the technology of the $1980 \mathrm{~s}$. This behaviour is reminiscent of the carelessness with which people treated questions of raw materials and the environment until recently. Many scientists are worried about the situation: it puts the Federal Republic at a disadvantage internationally; it also threatens those industrial nations which are short of raw materials, whose economies depend on the progress achieved in their laboratories.

The final decision on the relationship of pure research to applied research lies with the political authorities. They have never shown any special enthusiasm for pure research, which has little propaganda value for them in comparison with basic technological projects. Publicity and politics are not, as is often claimed, the enemies of science; they are simply indifferent to pure research. The "Gray Paper" ought to bring about a change of attitude. But will any of the politicians read it?

\section{The state of health of NIH}

\section{Colin Norman in Washington looks at the National Institutes of Health, just investigated by a Presidential Commission}

$\mathrm{O}$

$\mathrm{N}$ various occasions in the past few years, the National Institutes of Health (NIH), one of the largest and most prestigious biomedical research centres in the world, has been beset with personnel and budgetary upheavals. Two NIH directors have been fired, ostensibly for political reasons, repeated clashes between Congress and the Executive branch over the overall health budget have frequently thrown planning at NIH into utter confusion, and many of the agency's programmes have been suffering from chronic shortages of cash while others have been receiving relatively generous support. It has not been a very happy place.

The problems which have plagued $\mathrm{NIH}$ and. bv extension, the universities and medical schools whose work NIH supports, stem from a variety of sources. They range from the fact that NIH's budget has climbed to more than $\$ 2,000$ million a year, which makes the agency politically very visible, to false public hopes that medical science can produce swift solutions to complex health problems. But the chief irritant is clearly the 1971 National Cancer Act.

The instrument which officially launched the federal war on cancer, the act abruptly changed many established methods of supporting. planning and managing biomedical research. It also elevated the National Cancer Institute (NCI) to a privileged position in NIH, and caused vast sums of 